\title{
Les femmes font les titres du BMS
}

\section{Aufgaben der Arztfrau*.}

\section{Féminisme et chirurgie.}

\section{Zum Schwesternproblem.}

\section{Peu de femmes aux postes de cadre}

Pénurie de médecins: la solution vient-elle des femmes?

\section{Ärztinnen - die ewig Mitgemeinten}

\section{Wachsende Beliebtheit weiblicher}

Frauenärzte und Geburtshelfer

\section{Numéro 18, 1977}

La médecine se conjugue-t-elle au féminin? 